\title{
SOSIALISASI APLIKASI PEMBELAJARAN MATEMATIKA BERBASIS ANDROID PADA SD NEGERI 39 PALEMBANG
}

\author{
Evi Yulianti1), Suzan Agustri'2), Effy Luthfiyyah Nur ${ }^{3)}$, Desi Ratna Sari' ${ }^{4}$ \\ 1)23344)Program Studi Sistem Informasi Universitas Indo Global Mandiri \\ Jln. Jenderal Sudirman No. 629 Km 4, Palembang \\ Email: eviyulianti@uigm.ac.id ${ }^{11}$, zuzanoid@uigm.ac.id ${ }^{2)}$, effyluthfiyyahnur@gmail.com ${ }^{3)}$, \\ Desiratnasari@gmail.com ${ }^{4}$
}

\begin{abstract}
ABSTRAK
Program Sosialisasi Aplikasi Pembelajaran Matematika kelas 6 SD Negeri 39 Palembang berbasis Android ini merupakan wujud nyata kegiatan yang dilakukan dosen dan mahasiswa Universitas IGM membantu para guru SD Negeri 39 Palembang untuk meningkatkan kompetensi dalam kegiatan pengajaran. Saat ini smartphone difasilitasi dengan sistem operasi Android dan juga bersifat moveable sehingga akan lebih efektif untuk menunjang proses pembelajaran. Media pembelajaran multimedia atau berbasis android mampu menjadikan siswa lebih aktif, kreatif, lebih menyenangkan dan lebih semangat dalam belajar. Sosialisasi Aplikasi Pembelajaran Matematika berbasis Android dapat membantu siswa untuk belajar secara mandiri, pada aplikasi ini siswa dapat mempelajari materi pelajaran matematika terlebih dahulu. Setelah siswa membaca materi, siswa dapat menguji kemampuan mereka dengan cara menjawab soal tes matematika pada aplikasi ini. Aplikasi ini juga dapat mempermudah siswa untuk mengetahui nilai atau score dari hasil soal tes matematika mereka secara langsung, dan juga dapat mengetahui solusi penyelesaian dari masing-masing soal tes matematika tersebut. Aplikasi pembelajaran matematika berbasis android ini dirancang dengan tampilan yang sangat menarik dan interaktif, sehingga meningkatkan minat belajar siswa terhadap matematika.
\end{abstract}

Kata kunci : Android, aplikasi, pembelajaran multimedia

\section{PENDAHULUAN}

Pelajaran Matematika merupakan salah satu mata pelajaran yang diajarkan di Sekolah Dasar. Pelajaran matematika diberikan kepada siswa untuk melatih siswa agar berfikir sistematis, logis, kritis, kreatif dan konsisten. Matematika merupakan suatu perhitungan angka-angka yang tidak akan lepas dari kehidupan manusia. (Irwan Karim dan Andi Mariani, 2016). Metode pembelajaran khususnya pada mata pelajaran matematika yang ada saat ini pada umumnya hanya melalui buku catatan atau buku yang telah disediakan oleh pihak sekolah. Hal ini menyebabkan siswa kurang tertarik untuk belajar. Pembelajaran matematika yang menarik dan menyenangkan mampu menarik minat siswa untuk berperan aktif dalam proses pembelajaran. Salah satu cara pembelajaran matematika yang dianggap menyenangkan siswa yaitu penggunaan media visualisasi sebagai sarana pembelajaran.

Dengan seiringnya kemajuan teknologi informasi, metode pembelajaran akan selalu mengalami perubahan. Tujuan utama dari perubahan itu adalah untuk mengadakan pembaharuan guna meningkatkan minat belajar siswa. Media pembelajaran multimedia atau berbasis android mampu menjadikan siswa lebih aktif, kreatif, lebih menyenangkan dan lebih semangat untuk belajar.

\subsection{Bentuk Kegiatan}

Beberapa kegiatan yang dilakukan adalah:

a. Sosialisasi Media Pembelajaran Multimedia

b. Sosialisasi Aplikasi Pembelajaran Matematika berbasis Android.

\subsection{Tempat Kegiatan}

Kegiatan Pengabdian Masyarakat ini dilaksanakan di SD Negeri 39 Palembang, yang berlokasi di Jalan Kapten Marzuki, 20 ilir D. III Tim. 1, Kota Palembang, Sumatera Selatan. Telp. (0711) 321679. 


\subsection{Waktu Kegiatan dan Materi Pokok dalam Kegiatan}

Pelaksanaan kegiatan dilakkan dalam 1 (satu) hari. Adapun jadwal pelaksanaan adalah sebagai berikut:

Tabel 1. Jadwal Pelaksanaan Kegiatan

\begin{tabular}{|c|c|lr|}
\hline Tanggal Pelaksanaan & Waktu & \multicolumn{1}{|c|}{ Materi } \\
\hline \multirow{2}{*}{13 oktober 2018} & $09: 00-11: 30$ & $\begin{array}{l}\text { Sosialisasi Media Pembelajaran } \\
\text { Multimedia }\end{array}$ \\
\cline { 2 - 3 } & $13: 00-17: 00$ & $\begin{array}{l}\text { Sosialisasi Aplikasi } \\
\text { Pembelajaran Matematika } \\
\text { berbasis Android. }\end{array}$ \\
\hline
\end{tabular}

\subsection{Durasi Waktu Pelaksanaan Pelatihan}

Durasi waktu yang dibutuhkan selama pembuatan dan pelaksanaan kegiatan pengabdian pada masyarakat tersebut adalah sebagai berikut:

Tabel 2. Durasi Waktu Pembuatan dan Pelaksanaan Kegiatan

\begin{tabular}{|c|c|c|c|}
\hline KEGIATAN & TANGGAL & WAKTU & DURASI \\
\hline $\begin{array}{lll}\text { Terima } & \text { Surat } & \text { Pemohonan } \\
\text { Pelatihan } & & \end{array}$ & 08 Oktober 2018 & $10: 00$ & 1 jam \\
\hline $\begin{array}{l}\text { Rapat koordinasi kegiatan } \\
\text { Pelatihan }\end{array}$ & 08 Oktober 2018 & 09:00 - 16:00 & 7 jam \\
\hline $\begin{array}{l}\text { Terima Surat Tugas Dekan } \\
\text { Fasilkom untuk melakukan } \\
\text { pengabdian masyarakat }\end{array}$ & 11 Oktober 2018 & 9:00 & 1 jam \\
\hline $\begin{array}{l}\text { Pembuatan proposal kegiatan } \\
\text { Pelatihan }\end{array}$ & 11 Oktober 2018 & 09:00 - 12:00 & 9 jam \\
\hline Pembuatan materi ppt & 11 Oktober 2018 & $08.00-16.00$ & $24 \mathrm{jam}$ \\
\hline $\begin{array}{l}\text { Penyerahan dan pengesahan } \\
\text { proposal kepada Dekan Fakultas } \\
\text { Ilmu Komputer }\end{array}$ & 12 Oktober 2018 & 09:00 - 10:00 & 1 jam \\
\hline Konfirmasi kegiatan Pelatihan & 12 Oktober 2018 & $08: 00-16: 00$ & 8 jam \\
\hline $\begin{array}{l}\text { Pelatihan pertemuan } \\
\text { Suzan Agustri, M.T.I }\end{array}$ & 13 Oktober 2018 & $08.30-11.30$ & $3 \mathrm{Jam}$ \\
\hline $\begin{array}{l}\text { Pelatihan pertemuan II oleh oleh } \\
\text { Evi Yulianti, M.S.I }\end{array}$ & 13 Oktober 2018 & $13.00-16.30$ & $3 \mathrm{Jam}$ \\
\hline Foto bersama dengan para guru & 13 Oktober 2018 & $11.30-12.00$ & 30 Menit \\
\hline $\begin{array}{l}\text { Pembuatan laporan akhir kegiatan } \\
\text { pengabdian masyarakat }\end{array}$ & 18 Oktober 2018 & $13.00-17.00$ & 8 jam \\
\hline $\begin{array}{l}\text { Pengesahan laporan akhir } \\
\text { kegiatan pengabdian masyarakat }\end{array}$ & 19 Oktober 2018 & $09.00-10.00$ & 1 jam \\
\hline $\begin{array}{l}\text { Penyerahan dan pengesahan } \\
\text { laporan pengabdian } \\
\text { Ka. LP2MKPBarakat }\end{array}$ & 19 Oktober 2018 & $10.30-11.30$ & 1 jam \\
\hline
\end{tabular}




\section{Total Durasi Pelaksanaan pengabdian}

68.5 jam

Total durasi pelaksanaan pengabdian pada masyarakat untuk masing-masing pelaksana adalah:

Tabel 3. Total Durasi Pelaksanaan Kegiatan

\begin{tabular}{|c|c|l|c|c|}
\hline NO & NIDN/NPM & \multicolumn{1}{|c|}{ NAMA } & STATUS & $\begin{array}{c}\text { JUMLAH } \\
\text { DURASI }\end{array}$ \\
\hline 1 & 0228087803 & Suzan Agustri, M.T.I & Dosen/Narasumber & 68 jam \\
\hline 2 & 1003077602 & Evi Yulianti, M.S.I & Dosen/Narasumber & 68 jam \\
\hline 3 & $2017210099 P$ & Effy Luthfiyyah Nur & Mahasiswa/Asisten & 20 jam \\
\hline 4 & 2015210039 & Desi Ratna Sari & Mahasiswa/Asisten & $20 \mathrm{am}$ \\
\hline
\end{tabular}

\subsection{Landasan Teori}

\subsubsection{Aplikasi}

Aplikasi (Sutarto, 2009) adalah perangkat lunak yang digunakan untuk tujuan tertentu, seperti mengolah dokumen, mengatur Windows dan permainankan (game), dan sebagainya. (Sri Mulyani dan Winda Anggraeni, 2016). Menurut (Hendrayudi, 2008) Aplikasi adalah kumpulan perintah program yanng dibuat untuk melakukan pekerjaan-pekerjaan tertentu. (Sri Mulyani dan Winda Anggraeni, 2016).

Aplikasi adalah suatu unit perangkat lunak yang dibuat untuk melayani kebutuhan akan beberapa aktivitas tertentu yang saling terkait. (Hengky W. Pramana, 2006) (Sri Mulyani dan Winda Anggraeni, 2016).

1.5.2 Pembelajaran

Belajar adalah sebuah proses perubahan di dalam kepribadian manusia dan perubahan tersebut ditampakkan dalam bentuk peningkatan kualitas dan kuantitas tingkah laku seperti peningkatan kecakapan, pengetahuan, sikap, kebiasaan, pemahaman, keterampilan daya pikir, dan kemampuankemampuan yang lainnya.

Berikut ini adalah pengetahuan dan definisi belajar menurut beberapa ahli: Belajar (Slameto, 2003) adalah suatu proses usaha yang dilakukan seseorang untuk memperoleh suatu perubahan tingkah laku yang baru secara keseluruhan, sebagai hasil pengalamannya sendiri dalam interaksi dengan lingkungannya. Sedangkan Belajar menurut (Trianto, 2010) adalah proses belajar terjadi melalui banyak cara baik disengaja maupun tidak disengaja dan berlangsung sepanjang waktu dan menuju pada suatu perubahan pada diri pembelajar.

Pendapat (Ngalim Purwanto, 1992) Belajar adalah setiap perubahan yang relative menetap dalam tingkah laku, yang terjadi sebagai suatu hasil dari latihan atau pengalaman. (Sri Mulyani dan Winda Anggraeni, 2016).

\subsubsection{Matematika}

Matematika berasal dari bahasa latin manthanein atau mathema yang berarti belajar atau hal yang dipelajari. Matematika dalam bahas belanda disebut wiskunde atau ilmu pasti, yang kesemuanya berkaitan dengan penalaran. Ciri utama matematika adalah penalaran deduktif, yaitu kebenaran suatu konsep atau pernyataan diperoleh sebagai akibat logis dari kebenaran sebelumnya sehingga kaitan antar konsep atau pernyataan dalam matematika bersifat konsisten.

Salah satu pengertian matematika dari beberapa yang dikemukakan (Sujonoo, 1988) diantaranya matematika diartikan sebagai cabang ilmu tentang penalaran yang logic dan masalah yang berhubungan dengan bulangan. (Sri Mulyani dan Winda Anggraeni, 2016).(Karso, 1993) menyatakan matematika adalah ilmu tentang struktur yang bersifatdeduktif dan asiomatik, akurat, abstrak, ketat dan semacamnya. (Ni Made Sunilawati, dkk, 2013).

1.5.4 Android

Android merupakan sebuah sistem operasi perangkat mobile berbasis Linux yang mencakup sistem operasi, middleware dan aplikasi. Beberapa pengertian lain dari Android, yaitu: Merupakan platform terbuka (open source) bagi para pengembang (Programmer) untuk membuat aplikasi. Merupakan 
sistem operasi yang dibeli Google Inc. dari android Inc. Bukan bahasa pemrograman, tetapi hanya menyediakan lingkungan hidup atau run time environtment yang disebut DVM (Dalvik Virtual Machine) yang telah dioptimasi untuk alat/device dengan sistem memori yang kecil.

Untuk mengembangkan Android dibentuk OHA (Open Handset Aliance), konsorsium dari 34 perusahaan peranti keras (Hardware), peranti lunak (Software), dan telekomunikasi, termasuk Google, HTC, Intel, Motorola, Qualcomm, T-Mobile, dan Nvidia.

1.5.5 Perangkat Pendukung

Adapun perangkat pendukung yang digunakan dalam pembuatan aplikasi ini adalah sebagai berikut:

1. Perangkat keras (Hardware)

Perangkat keras (Hardware) adalah peralatan di sistem komputer yang secara fisik dapat dilihat dan digunakan. (Asropudin, 2013).

Adapun perangkat keras yang digunakan yaitu sebagai berikut:

a. Smartphone Android

b. Android versi Jelly bean v4.1.2

c. RAM $1,5 \mathrm{~GB}$

2. Perangkat Lunak (Software)

Perangkat lunak (Software) adalah program yang berisi perintah-perintah/ instruksi-instruksi untuk melaksanakan pengolahan data. (Emy Budi Susilowati dan Bambang Eka Purnama, 2011)

Adapun perangkat lunak yang digunakan yaitu sebagai berikut:

a. Eclipse, yang digunakan untuk mendesain tampilan form pada aplikasi.

b. Server Web XAMPP

c. Bahasa pemrograman JavaScript, yang digunakan untuk membuat aplikasi

d. Database Server MySQL

e. ClickChart, yang digunakan untuk merancang aplikasi.

\section{TARGET DAN LUARAN}

\subsection{Target}

Target kegiatan ini adalah Sosialisasi Aplikasi Pembelajaran Matematika Berbasis Android kelas 6 SD yang membantu para Guru Pada SD Negeri 39 Palembang untuk memantau dan kemampuan para siswa.

1 Meningkatkan minat siswa untuk mempelajari matematika $80 \%$

2 Memudahkan kegiatan proses pembelajaran $80 \%$

3 Siswa mampu belajar secara mandiri $80 \%$

\subsection{Luaran}

Target Luaran dari Sosialisasi Aplikasi Pembelajaran Matematika Berbasis Android kelas 6 SD Negeri 39 Palembang yaitu :

1 Meningkatkan minat siswa untuk mempelajari matematika $70 \%$

2 Memudahkan kegiatan proses pembelajaran $75 \%$

3 Siswa mampu belajar secara mandiri $70 \%$

4 Laporan Akhir hasil pengabdian kepada masyarakat akan dipublikasikan pada junal ABDIMAS UIGM

\section{METODE PELAKSANAAN PENGABDIAN}

\subsection{Kegiatan}

Program Pelatihan ini adalah Sosialisasi Pembuatan Aplikasi Pembelajaran Matematika berbasis Android yang dilaksanakan hari sabtu tanggal 13 oktober 2018 dimulai dari jam 9.00 s.d jam 17.00. Sosialisasi Aplikasi Pembelajaran Matematika berbasis Android dilaksanakan dengan metode ceramah, diskusi dan praktek. Diskusi dilakukan secara terbuka, Praktek langsung dilakukan didepan komputer, masing-masing perserta menggunakan laptop. 


\subsection{Peserta}

Kegiatan Pengabdian kepada masyarakat ini di ikuti oleh para Guru SD Negeri 39 Palembang.

\subsection{Proses Kegiatan}

Proses kegiatan dilaksanakan dalam 1 (satu) kali pertemuan adalah sebagai berikut:

Tabel 4. Proses Kegiatan

\begin{tabular}{|c|c|l|}
\hline WAKTU & \multicolumn{1}{|c|}{ MATERI } & \multicolumn{1}{c|}{ FASILITATOR } \\
\hline Sabtu, 13 0ktober 2018 & \multicolumn{1}{|c|}{} \\
\hline 07:30 - 08:00 & Registrasi & Panitia dari Mahasiswa \\
\hline 08:00 - 08:30 & Pembukaan & $\begin{array}{l}\text { Kepala SD Negeri 39Palembang } \\
\text { Hj. Linda Ermellya S.Pd,M.Si }\end{array}$ \\
\hline 08:30 - 09:00 & Pembukaan & Ketua Pelaksanaan \\
\hline 09:00 - 12:00 & $\begin{array}{c}\text { Sosialisasi Media } \\
\text { Pembelajaran Multimedia }\end{array}$ & Suzan Agustri, M.T.I \\
\hline 13:00 - 16:30 & $\begin{array}{c}\text { Sosialisasi Aplikasi } \\
\text { Pembelajaran Matematika } \\
\text { berbasis Android. }\end{array}$ & Narasumber : Evi Yulianti, M.SI \\
\hline 16:30 - 17:00 & Penutupan & $\begin{array}{l}\text { Ketua Pelaksanaan Pengabdian } \\
\text { Masyarakat }\end{array}$ \\
\hline
\end{tabular}

\section{HASIL DAN PEMBAHASAN}

Dengan adanya perancangan aplikasi pembelajaran matematika, diharapkan dapat meningkatkan minat belajar siswa dengan tidak mengurangi esensi daripada peranan guru untuk memberikan penjelasan mengenai materi kepada siswa.

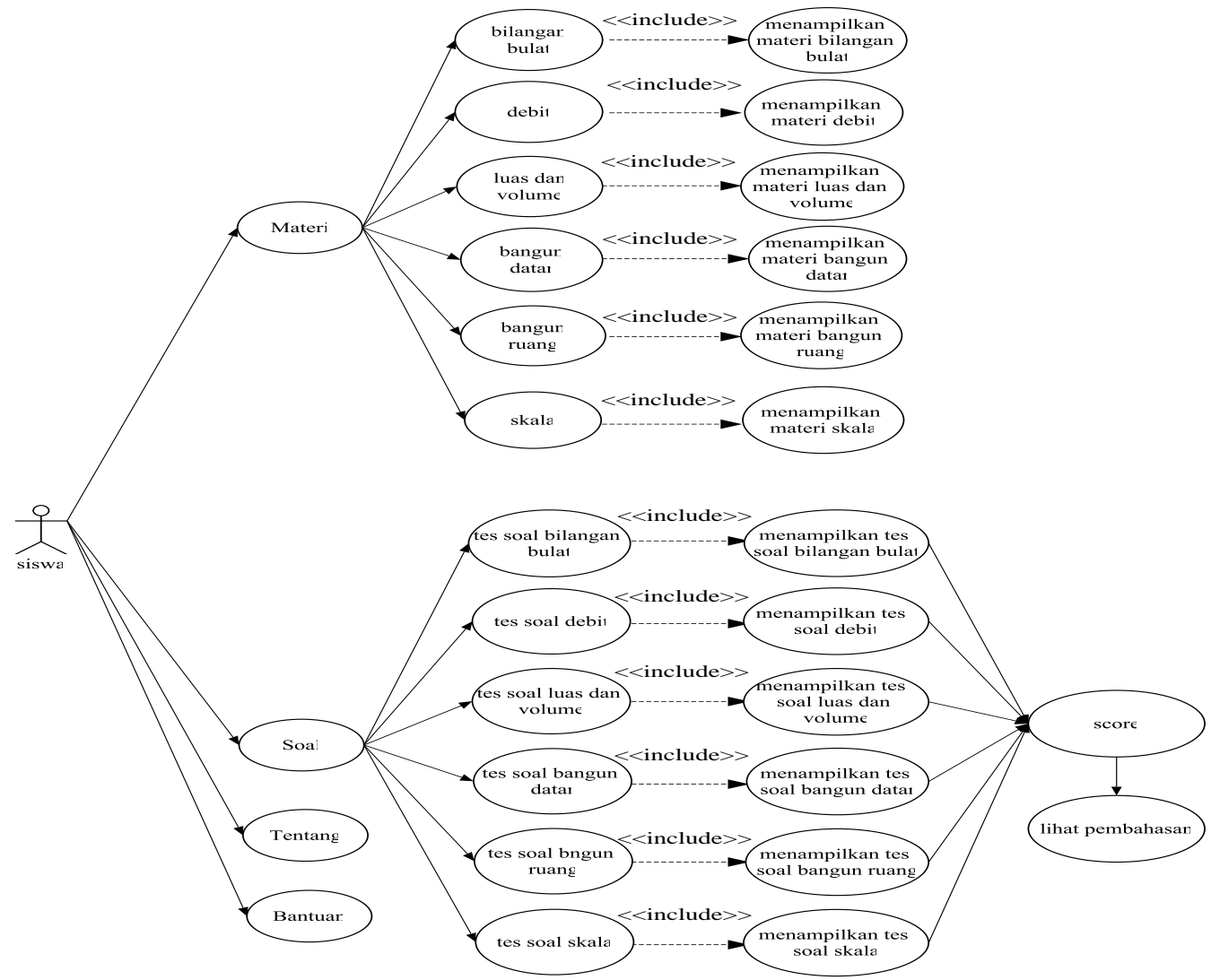

Gambar 1. Aplikasi Android 


\subsection{Penyampaian Materi Pelatihan}

Sosialisasi Aplikasi Pembelajaran Matematika berbasis Android ini akan dilaksanakan selama 1 (satu) hari yang dilaksanakan pada tanggal 13 oktober 2018 yang penyampaian Sosialisasi Media Pembelajaran Multimedia dan Sosialisasi Aplikasi Pembelajaran Matematika berbasis Android.

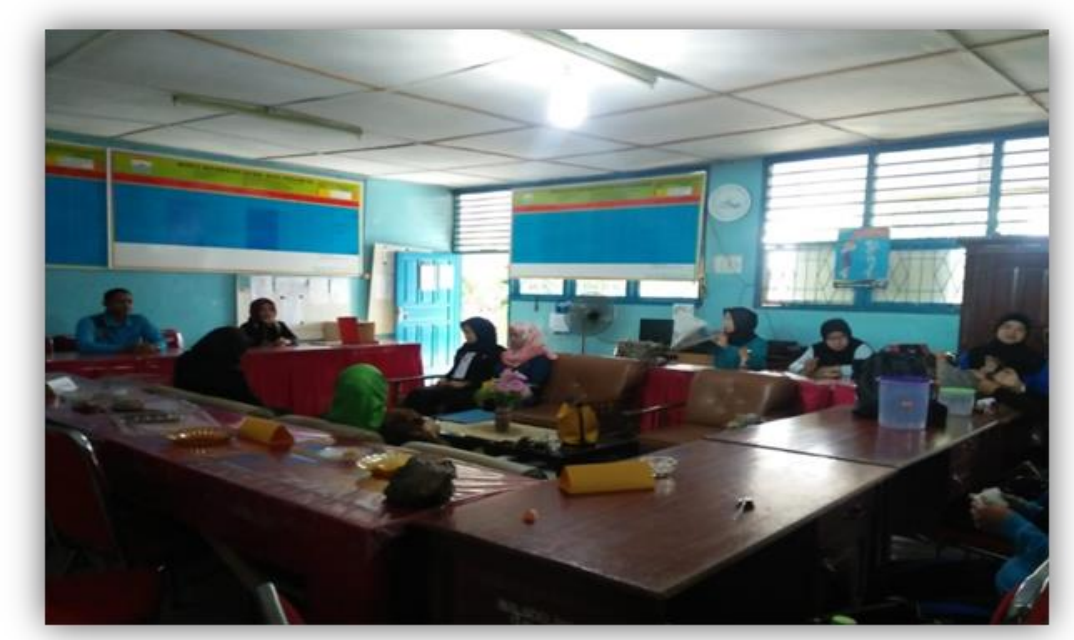

Berikut merupakan tampilan Menu Utama dari Aplikasi Pembelajaran Matematika berbasis Android. Siswa dapat mengklik menu pilihan yang terdiri dari Materi, Soal, Tentang, dan Bantuan.

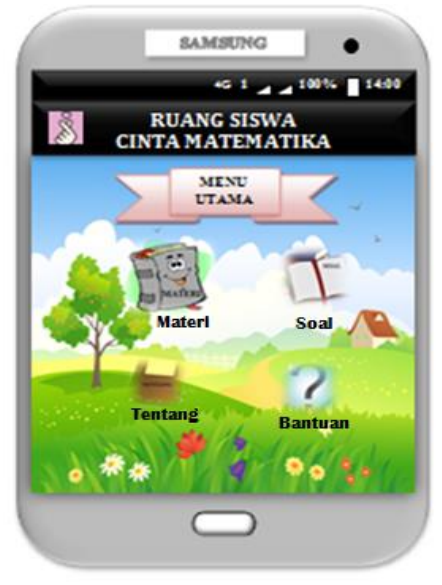

Gambar 2. Menu Utama

\subsection{Menu Pilihan Materi}

Menu materi berisikan pokok bahasan Matematika kelas 6 (enam) SD. Ada 6 pokok bahasan yang dijelaskan sesuai kurikulum pendidikan yaitu Bilangan Bulat, Debit, Luas dan Volume, Bangun Datar, Bangun Ruang, dan Skala.

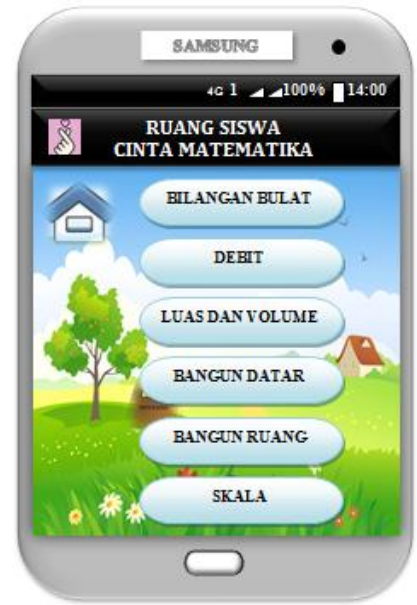

Gambar 3. Menu Pilihan 


\subsection{Materi Bahasan Soal}

Materi berisikan pokok pembahasan Matematika kelas 6 (enam) SD yang sesuai kurikulum pendidikan.

\subsection{Soal Tes}

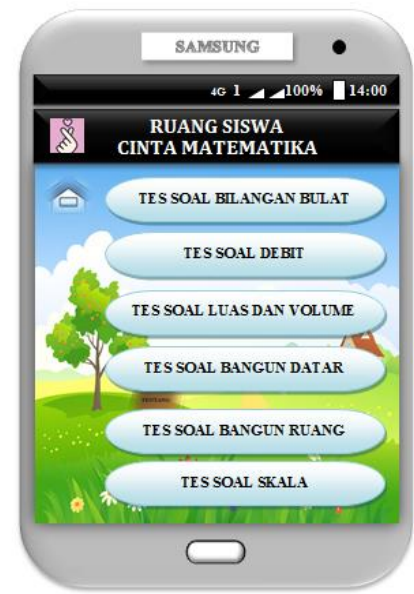

Gambar 4. Pilihan Soal

Setiap pokok pembahasan terdapat 100 soal dengan pilihan ganda. Tampilan soal tes dapat di lihat pada gambar di bawah ini:

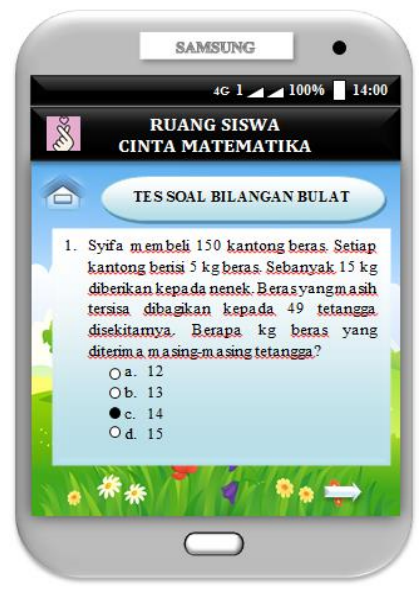

Gambar 5. Soal Tes

\subsection{Halaman Isi Soal}

Halaman isi soal berisikan tes soal dari setiap pokok pembahasan Matematika kelas 6 (enam) SD yang sesuai kurikulum pendidikan. Setiap pokok pembahasan terdapat 100 soal dengan pilihan ganda.

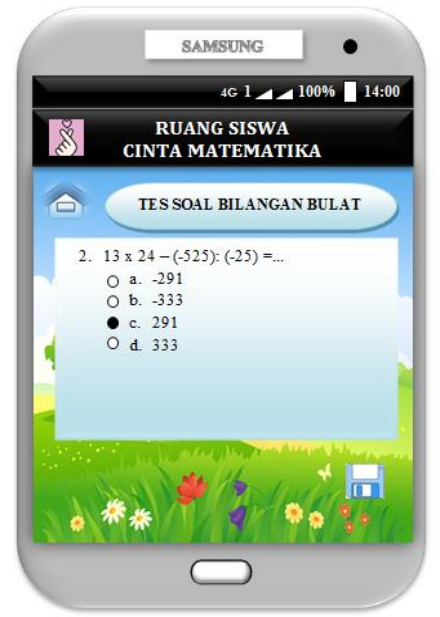

Gambar 6. Soal Bilangan Bulat 
Tanda panah tanda melanjutkan ke soal berikutnya, setelah siswa selesai menjawab 100 soal, maka siswa harus klik tombol save.

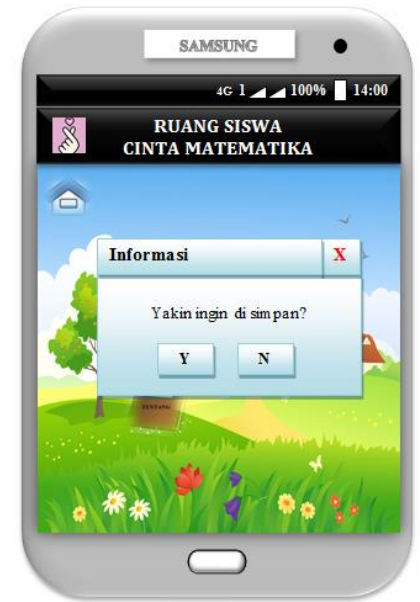

Gambar 7. Simpan hasil tes

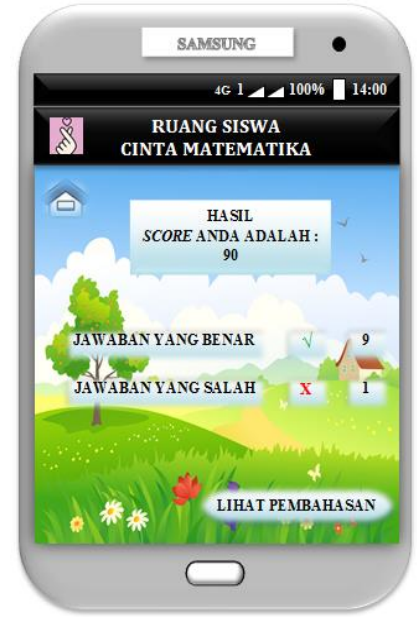

Gambar 8. Score

Selanjutnya klik button Lihat Pembahasan.

\subsection{Pembahasan}

Pembahasan menjelaskan masing-masing tes soal.

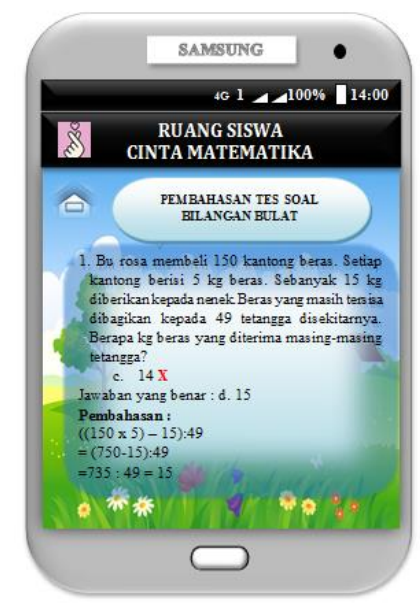

Gambar 9. Pembahasan

\subsection{Menu Tentang}

Menu pilihan ini menerangkan Riwayat pembuat aplikasi pembelajaran matematika kelas 6 (enam) SD berbasis android. 


\subsection{Menu Bantuan}

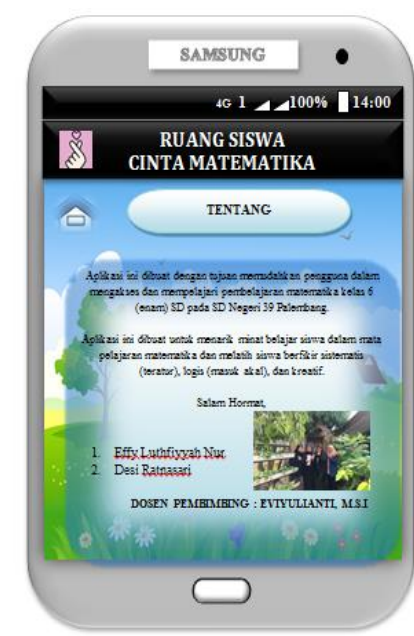

Gambar 10. Tentang

Menu bantuan dibuat dengan tujuan untuk menjelaskan kepada pengguna cara penggunaan dari aplikasi pembelajaran matematika kelas 6 (enam) SD berbasis android.

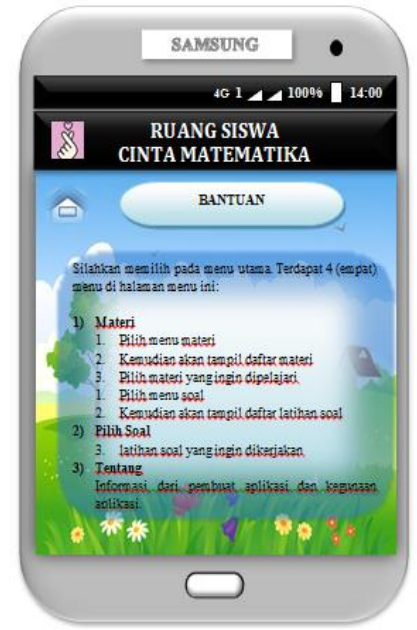

Gambar 11. Menu Bantuan

\section{KESIMPULAN}

Dengan dikembangkannya program Aplikasi pembelajaran matematika Berbasis Android ini dapat dijadikan sebagai media penunjang pembelajaran antara guru dan siswa untuk mempelajari matematika. Aplikasi akan mudah dipahami siswa dengan berbagai fitur aplikasi yang dilengkapi dengan materi, tes soal, tentang, score, tentang maupun bantuan, sehingga siswa tertarik untuk menggunakan aplikasi pembelajaran matematika Berbasis Android. Dengan adanya Aplikasi Pembelajaran Matematika Kelas 6 SD Pada SDN 39 Palembang dapat meningkatkan motivasi dan semangat belajar siswa, meningkatkan hasil belajar siswa pada mata pelajaran matematika, dapat membantu siswa belajar secara mandiri, dan mempermudah siswa untuk menguji kemampuan matematikanya.

\section{DAFTAR PUSTAKA}

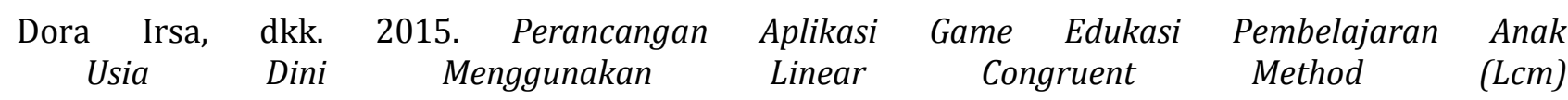
Berbasis Android. Vol 6, No.1.

Indrajani. 2015. Database Design. Jakarta: PT. Elex Media Komputindo.

Irwan Karim dan Andi Mariani. 2016. Aplikasi Pembelajaran Matematika Kelas III SD Berbasis Android. JTII, Vol. 1, No.1 
Mulyani, Sri dan Winda Anggraeni. 2016. Rancang Bangun Aplikasi Pembelajaran Matematika SD Kelas 6 Berbasis Android Pada SDN Cimone 1 Tangerang. Vol I, No. 2.

Munawar. 2005. Pemodelan Visual dengan UML. Yogyakarta: Graha Ilmu.

Rosa dan Shalahuddin. 2014. Rekayasa Perangkat Lunak Terstruktur dan Berorientasi Objek. Bandung: Informatika Bandung.

Rosa, Friska Octavia. 2015. Pengembangan Modul Pembelajaran Ipa Smp Pada Materi Tekanan Berbasis Keterampilan Proses Sains. JPF. Vol. III, No. 1.

Slamet dan Samsul Maarif. 2014. Pengaruh Bentuk Tes Formatif Assosiasi Pilihan Ganda Dengan Reward Dan Punishment Score Pada Pembelajaran Matematika Siswa SMA. Vol 3. No.1.

Sunilawati, Ni Made, dkk. 2013. Pengaruh Model Pembelajaran Kooperatif Tipe Stad Terhadap Hasil Belajar Matematika Ditinjau Dari Kemampuan Numerik Siswa Kelas IV SD. Volume 3. Vol 3, No 4.

\section{Dokumentasi}
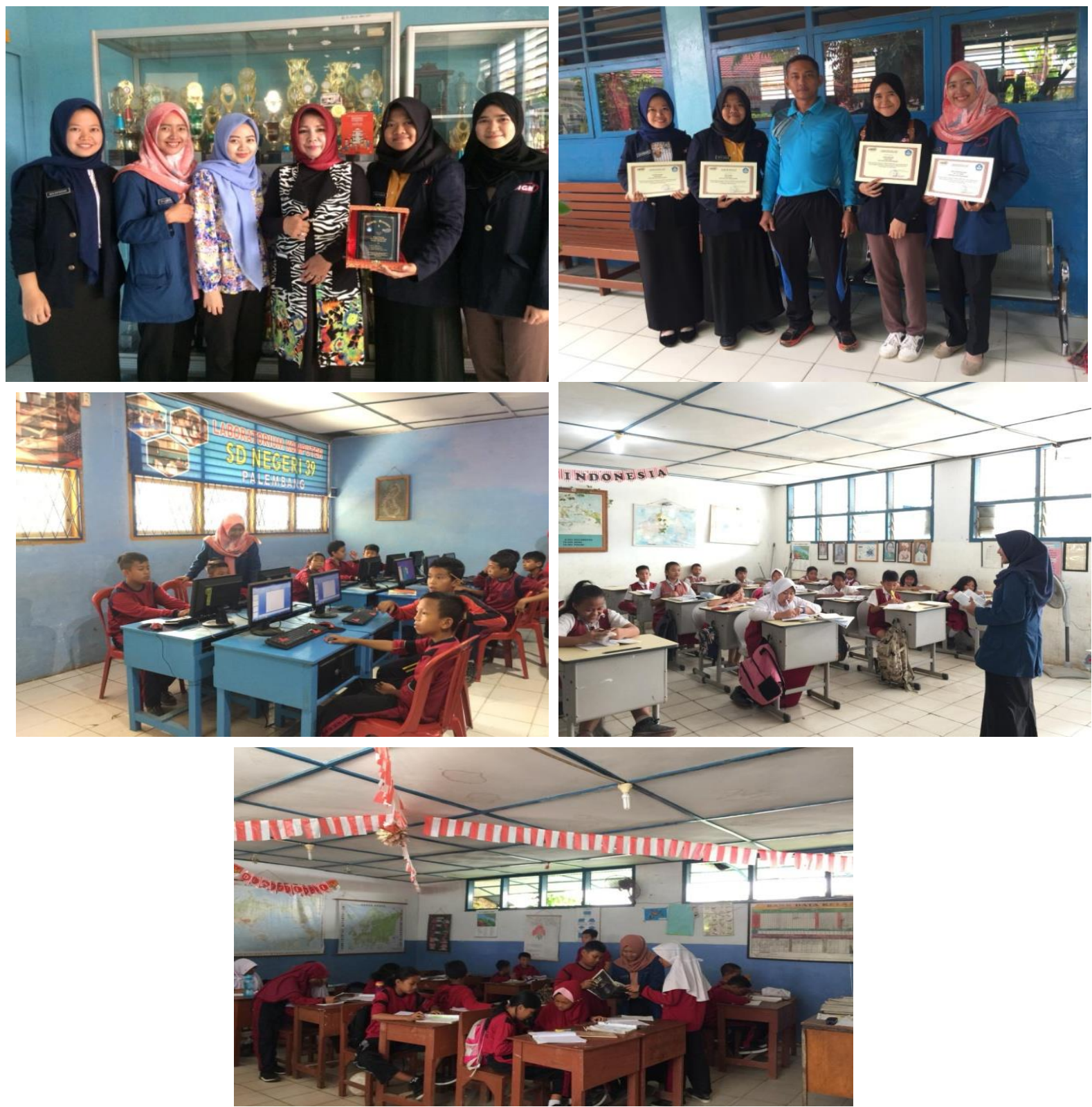